\title{
Why Political Parties don't and do Matter in Local Government Elections in Indonesia: A Manado Case
}

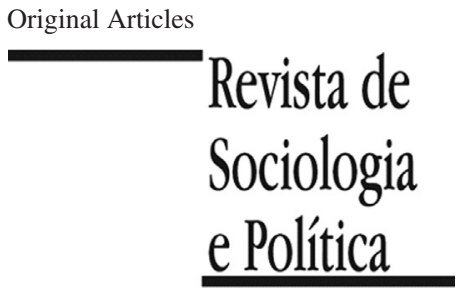

DOI 10.1590/1678-987321297703

\author{
Stefanus Sampel iD \\ ${ }^{\text {I} G o v e r n m e n t ~ S c i e n c e ~ P r o g r a m, ~ F a c u l t y ~ o f ~ S o c i a l ~ a n d ~ P o l i t i c a l ~ S c i e n c e s, ~ U n i v e r s i t a s ~ S a m ~ R a t u l a n g i, ~ M a n a d o, ~ I n d o n e s i a . ~}$ \\ Keywords: Decentralization; Developing Countries; Indonesia; Local Elections; Political Parties.
}

\begin{abstract}
Introduction: Despite decentralization devolving increasing decision-making powers to subnational governments across Asia, the subject of local-level elections has not received anywhere near the academic attention afforded to national elections. This article aims to make a contribution to filling this gap in the literature on the dynamics of local election by examining the political parties' activities in the 2010 local executive election in Indonesia through the detailed case study of Manado City. Materials and Methods: This article used a combination of quantitative and qualitative methodologies for a case study of the Manado local government election in 2010. These methods include direct observation which had been done during the election in 2010, review of relevant media articles and books, collection of statistics from relevant government organizations and interviews. The latter comprised the most important and novel aspect of the research. The interviews were of two types: First, there was a quantitative survey of 100 selected voter respondents using questionnaire with 22 closed-ended questions. Second, there were semi-structured interviews with the local leaders of political parties, the heads of campaign teams, the candidates, the members of the local electoral organization, the representatives of NGOs, mass media personnel and the survey organisations who monitored the election. The quantitative data was explored with the aid of a computer application program (SPSS) while the qualitative data was analysed through a thematic approach. Although the qualitative data collection and analysis was dominant, the quantitative methodology was still important in this article. Results: This article found a paradoxical situation in that political parties did not and did matter. They did not matter case was supported by evidence showing that voters chose candidates based on their personalities, behaviours and programs rather than on party loyalty. On the contrary, they did matter case derived from the superior organisational abilities of parties in running successful election campaigns and in aligning themselves with the candidates most likely to win. Discussion: This article had made a valuable addition to explaining the activities of political parties at local level in the context of decentralization. The implication of this research is that although voters did not choose political parties, the latter were nonetheless highly significant in determining the outcome of the local government election in Manado City. So, it is useful for future research to consider more closely the role of parties in local elections.
\end{abstract}

Received in December 4, 2019. Approved in September 28, 2020. Accepted in November 25, 2020.

\section{Introduction}

$\mathrm{T}$ he twin trends of democratization and decentralization have meant that local government elections have become ubiquitous in developing countries. So pronounced has been the attraction of local elections that even one-party states such as China and Vietnam have joined the subnational electoral bandwagon, albeit in a cautious and restricted manner (Ho, 2014; Mattner, 2004). The proliferation of local-level elections in the developing world has not, however, been reflected in academic interest. There are numerous studies of national elections, sometimes focusing on local areas, and the role of political parties in those elections. There has also been a burgeoning literature on various aspects of decentralization covering topics such as accountability, finance and service delivery (Litvack, Ahmad \& Bird, 1998; Bardhan \& Mookherjee, 2006; Cheema \& Rondinelli, 2007; World Bank, 2005). However, the dynamics of local elections and the activities of political parties have been largely overlooked.

Local-level elections can be important components of political life. In developing countries such as Indonesia and the Philippines, considerable responsibilities and finance have been devolved to locally elected councils (Lewis, 2005; Turner, 2006). Local politics is inextricably linked to regional or national politics while local government can be a stepping stone to higher office such as 
by President Widodo in Indonesia and President Duterte in the Philippines. In Indonesia the twin trends of democratization and decentralization bring major changes to the country's political organization and processes. Much has been written on these changes but one aspect about which there has been little published is local government elections, apart from the pioneering collection of case studies edited by Erb and Sulistiyanto (2009) on the 2005 and 2006 local elections.

This article contributes to the understanding of the dynamics of local government elections in Indonesia. Through in-depth analysis of one specific local election - the 2010 election for the mayor of Manado City - the nature of local political interaction among candidates, parties and voters can be observed. While the interaction is mainly at the local level, the involvement of parties means that national actors and forces also come into play in the local political arena. The examination of the actors and political processes that occurred during the 2010 local government election in Manado City led to the argument that political parties both do and don't matter. This seeming paradox is created through the dynamics of the nomination of candidates, the actions of political parties and the perceptions of voters.

\section{Political Parties in Local Election in Indonesia}

Local elections and political parties were features of the authoritarian rule of President Soeharto. Three parties were permitted but only the government and militarily-backed Golkar party won under the electoral authoritarian system (Devas, 1997). The "elected" local governments were merely conduits for implementing central government policy and maintaining order. The deconcentrated units of central government agencies held much of the authority at the local level and accounted for far greater spending than the local governments (Rohdewohld, 1995). The overthrow of Soeharto led to profound changes in the organization of the state, the distribution of government functions and finance, and the mode of selecting leaders (Holtzappel \& Ramstedt, 2009; Turner \& Podger, 2003). Districts (kabupaten and kota) rather than provinces (propinsi) were the big winners. Under Laws 22 and 25 of 1999, most service delivery functions and the substantial funds to pay for them were decentralized to the kabupaten and kota. Political power at the subnational level was vested in local parliaments (Dewan Perwakilan Rakyat Daerah - DPRD) whose members were elected by popular vote. Restrictions on political parties were relaxed so that by the time of the 2009 national election there were 38 parties competing nationwide.

The most prized position in subnational government is the local chief executive (bupati in kabupaten and walikota in kota) as the holder commands most power in the government. Thus, competition for this position has been intense in the era of democratic decentralization (Erb \& Sulistiyanto, 2009). Before 2005 , the heads of local government were chosen by the political parties that had seats in the DPRD but since then there have been direct popular elections for the office. The elections did not, however, start simultaneously in all regions of Indonesia. There were 224 in 2005 and 81 in 2006 (Satriyo, 2010). But in all cases, political parties have been heavily involved in recruiting, nominating and campaigning for their candidates.

Recruitment of candidates for the local executive election is conducted in the first instance by the local branches of political parties. However, central offices retain the power to veto local choices and can demand review or insist on the adoption of their preferred candidate. In Tsebelis's (2002) terms, the national party offices are "veto players" and are known to use their veto power to override local preferences for candidates in the local executive elections. Gen- 
erally, central party control is strong and means that local branches lack the autonomy to insist on the nomination of their chosen candidates. Internal party conflict between local party branches and central offices can occur where local and central choices differ. Such internal conflicts can cause particular difficulties for local party branches as they frequently must build coalitions with other parties to support a candidate. With a candidate vetoed by the central office and a new one adopted, the local party branch must renegotiate its commitments to local coalitions of parties.

The practice of forming coalitions in support of a set of candidates (head and deputy head of region) derives from The Regulation of the Indonesian Electoral Commission No. 13/2010 which gives the right to nominate candidates to political parties having 15 per cent or more of the total number of seats in the DPRD or getting 15 per cent of the total vote in the previous legislative election. A political party that does not satisfy these requirements must join with other parties to reach the 15 per cent of seats or votes needed to nominate candidates. Even when a party meets the 15 per cent on its own, it may still enter into coalition with other parties to enhance the candidates' chances of victory. It has been suggested that this does not seem to raise concerns among parties and their followers about ideological compromises. According to Pratikno (2009), in the 2005 and 2006 local executive elections, there were no barriers preventing any party forming election partnerships with any other party. But, "the members of parties in each coalition have still used their ideological lines and networks to mobilize votes" (Pratikno, 2009, p. 65).

In Indonesia, parties have been active in all electorates for the local executive elections but evidence from the first direct elections for district heads (pilkada) in 2005 and 2006 suggests that party allegiance may not have been a significant factor in determining election outcomes (Mboi, 2009; Mujani \& Liddle, 2009). For example, in Choi's (2009, p. 85) study, the most striking feature of the 2005 Batam mayoral election "was the almost total absence of parties, party machines and party platforms". Buehler (2009) noted the declining role of parties and their influence in the South Sulawesi district governor elections in 2005 while Subianto (2009) observed the greater significance of ethnic and religious politics in West Kalimantan rather than party allegiances. Lindsay (2009, p. 215) found that in the direct elections of bupatis in Jogjakarta "voters no longer chose parties, but people" and that party symbols did not appear on billboards advertising the candidates. In some districts, Hidayat (2009) saw the rise of various forms of money politics. Material rewards for supporters rather than programmes and party ideologies had greater prominence in these electorates. By contrast Erb and Anggal (2009) found that voters were more concerned with "visi dan misi" (vision and mission) and experience rather than the manipulation of traditional characteristics, such as aristocratic lineage, kinship and support of traditional institutions. In summary, the case studies for the 2005-2006 local government elections, revealed that parties did not appear to figure much in the citizens' calculations about who to vote for. Furthermore, success at national level in a particular constituency for a party was not necessarily a good predictor of the distribution of votes in the pilkada (Erb \& Sulistiyanto, 2009).

The overall picture of the first pilkada is one in which differences between constituencies resulted in contrasting electoral dynamics and processes across Indonesia. There was no standard model. However, one matter on which the author of the first pilkada studies agreed was that in all constituencies, political parties played peripheral roles in determining who would be elected. This article now moves on to the second executive elections in Indonesia in 2010 to see whether there had been changes in political party roles and significance. Were 
the observations of 2005 and 2006 still valid? This question will be pursued using the case of Manado City.

\section{The Case of Manado City}

Manado City, a kota, is the capital of North Sulawesi Province and located in the northern peninsula of Sulawesi island. In 2010, the population was 410,481 and showed diversity in ethnicity, religion, education and occupation. Minahasa, Sangihe, Bantik, Gorontalo, Javanese, Borgo and Chinese are the dominant ethnic groups. Unusually for Indonesia, Christians comprised the majority of the population (67 per cent) with Muslims as the second largest religious group (31 per cent) (BPS Sulut, 2010). In terms of education 32.5 per cent of the population had completed senior secondary school but relatively few continue their studies to university level (BPS Sulut, 2010). Regarding occupation, in 2010, 41 per cent of the workforce were classified as "public servants, teachers and employees in the private sector". Businesspersons comprised 21 per cent of the workforce, merchants 13 per cent and farmers, ranchers and fishermen 9 per cent, and unskilled labourers 9 per cent (BPS Sulut, 2010). The city has experienced relatively strong economic growth, fluctuating between 8.4 per cent and 8.8 per cent between 2008 and 2011, with tertiary sectors dominating the economy.

The direct local executive elections have been held in Manado City three times. The last local executive election was in 2016 and contested by three pairs of candidates nominated by political parties. The first election was in 2005 when six pairs of candidates contested. All pairs of candidates were also nominated by political parties. The winner was unable to complete his term having been found guilty in a corruption case. His successor met the same fate, and then the Governor of North Sulawesi Province took over until the 2010 election. In this contest, there were nine pairs of candidates, six being nominated by political parties. The numbers of parties supporting individual candidates varied from eleven to one. The campaigns were highly competitive and boisterous and multiple infringements of electoral rules were reported (Tribun Manado, 2010a; 2010b). When the votes were counted, the pair of Vicky Lumentut and Harley Mangindaan were clear winners with 35.7 per cent of the vote (see Table 1). This result did not satisfy the other candidates, two pairs of whom brought their formal complaints to the Constitutional Court. The Court ruled that there had been "massive, systemic and structured infringements" - pelanggaran yang masif, sistemis dan terstruktur. The Court ordered KPUD Manado to re-run the election, the first time such an instruction had been issued in Indonesia. The new election was held in October 2010, barely two months after the first one. Twenty-seven parties were involved in coalitions supporting six pairs of candidates while three pairs stood as independents. The winners from the first contest triumphed again, and with a much increased share of the vote: 49.4 per cent. The runners-up, the complainants to the Constitutional Court, also improved their share of the vote to 37.1 per cent while the other seven pairs each attracted under

7 per cent of the vote. Turnout was lower, declining from 210,606 in the first vote to 189,776 in the second. The analysis in the following sections concerns this re-run election in Manado City.

A case study approach was adopted for this research that involved direct observation of the 2010 local executive elections, review of relevant media articles, collection of statistics from relevant government organizations and interviews. The latter comprised the most important and novel aspect of the research. The interviews were of two types. First, there was a quantitative survey of voters to investigate the reasons for their choice of candidates. The questionnaire was comprised of seven questions on the respondents' demographic data 
Table 1 - Candidates, nominating parties and results of the 2010 local government elections in Manado City

\begin{tabular}{|c|c|c|c|c|c|c|c|c|}
\hline \multirow[t]{2}{*}{ No } & \multirow[t]{2}{*}{ Candidates } & \multirow[t]{2}{*}{ Nominating Parties } & \multicolumn{2}{|c|}{ The 2009 legislative election } & \multicolumn{2}{|c|}{$\begin{array}{l}\text { The first voting of local exe- } \\
\text { cutive election in } 2010\end{array}$} & \multicolumn{2}{|c|}{$\begin{array}{l}\text { Repeat Voting of local execu- } \\
\text { tive election in } 2010\end{array}$} \\
\hline & & & Votes & $\%$ & Votes & $\%$ & Votes & $\%$ \\
\hline 1. & Djeli Massie - Harry Pontoh & Independent & $25,530^{*}$ & 12.54 & 969 & 0.46 & 204 & 0.11 \\
\hline \multirow[t]{9}{*}{2.} & Jackson Kumaat - Helmi Bachdar & Partai Hanura & 7,544 & 3.6 & & & & \\
\hline & & PKS & 7,183 & 3.53 & & & & \\
\hline & & PDK & 3,906 & 1.92 & & & & \\
\hline & & Partai Buruh & 2,816 & 1.38 & & & & \\
\hline & & PMB & 443 & 0.22 & & & & \\
\hline & & PKP & 469 & 0.23 & & & & \\
\hline & & PSI & 299 & 0.15 & & & & \\
\hline & & PKNU & 186 & 0.09 & & & & \\
\hline & & TOTAL & 24,586 & 11.12 & 17,275 & 8.20 & 1,434 & 0.76 \\
\hline \multirow[t]{12}{*}{3.} & Burhanuddin - Jacobus Mawuntu & PPRN & 3,800 & 1.87 & & & & \\
\hline & & Partai Kedaulatan & 1,816 & 1.27 & & & & \\
\hline & & PPD & 3,153 & 1.55 & & & & \\
\hline & & PKB & 4,482 & 2.20 & & & & \\
\hline & & PPDI & 1,239 & 0.61 & & & & \\
\hline & & Partai Pelopor & 1,977 & 0.97 & & & & \\
\hline & & PPP & 8,889 & 4.37 & & & & \\
\hline & & PNBK & 2,191 & 1.08 & & & & \\
\hline & & PBB & 1,364 & 0.67 & & & & \\
\hline & & PBR & 3,390 & 1.67 & & & & \\
\hline & & PKDI & 3,310 & 1.63 & & & & \\
\hline & & TOTAL & 37,351 & 17.89 & 5,593 & 2.65 & 1,092 & 0.58 \\
\hline 4. & Louis Nangoy - Rizali M Noor & Independent & $39,838^{*}$ & 19.57 & 7,404 & 3.51 & 1,329 & 0.7 \\
\hline \multirow[t]{2}{*}{5.} & Hanny Pajouw - Anwar Panawar & Partai Golkar & 33,934 & 16.67 & & & & \\
\hline & & PAN & 9,213 & 4.53 & & & & \\
\hline
\end{tabular}




\begin{tabular}{|c|c|c|c|c|c|c|c|c|}
\hline \multirow[t]{2}{*}{ No } & \multirow[t]{2}{*}{ Candidates } & \multirow[t]{2}{*}{ Nominating Parties } & \multicolumn{2}{|c|}{ The 2009 legislative election } & \multicolumn{2}{|c|}{$\begin{array}{c}\text { The first voting of local exe- } \\
\text { cutive election in } 2010\end{array}$} & \multicolumn{2}{|c|}{$\begin{array}{l}\text { Repeat Voting of local execu- } \\
\text { tive election in } 2010\end{array}$} \\
\hline & & & Votes & $\%$ & Votes & $\%$ & Votes & $\%$ \\
\hline \multirow{5}{*}{6.} & \multirow{5}{*}{ Yongkie Limen - Marietha Kuntag } & Barnas & 6,554 & 3.22 & & & & \\
\hline & & TOTAL & 49,701 & 24.42 & 48,785 & 23.16 & 70,445 & 37.12 \\
\hline & & Partai Gerindra & 11,158 & 5.48 & & & & \\
\hline & & PKPB & 5,386 & 2.65 & & & & \\
\hline & & TOTAL & 16,544 & 8.13 & 21,293 & 10.11 & 12,354 & 6.51 \\
\hline 7. & Wempie Frederik - Richard Kainage & Independent & $23,918 *$ & 11.75 & 9,170 & 4.35 & 934 & 0.49 \\
\hline 8. & $\begin{array}{l}\text { Vicky Lumentut - Harley } \\
\text { Mangindaan }\end{array}$ & Partai Demokrat & 28,719 & 14.11 & 75,266 & 35.73 & 93,833 & 49.44 \\
\hline \multirow[t]{3}{*}{9.} & \multirow[t]{3}{*}{ Marhany Pua - Richard Sualang } & PDIP & 26,230 & 12.89 & & & & \\
\hline & & PDS & 7,362 & 3.62 & & & & \\
\hline & & TOTAL & 33,592 & 16.51 & 24,851 & 11.79 & 8,151 & 4.3 \\
\hline Tot & & & & & 210,606 & & 189,776 & \\
\hline
\end{tabular}

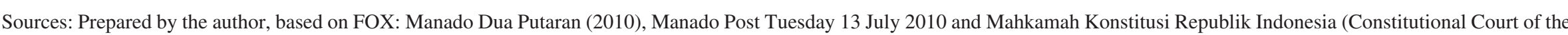
Republic of Indonesia), Decision of the Constitutional Court of the Republic of Indonesia No. 144/PHPU.D-VIII/2010.

"Number of photocopy Identity Cards of their supporters. 
such as gender, age, level of education and occupation; and 22 closed-ended questions sought the people's view on the factors encouraging them to vote in the election. The survey population was all registered voters in the 2010 Manado local election. A stratified purposive sample of 100 voter respondents was used. They were drawn from all nine sub-districts (kecamatans) of Manado City as the political parties and candidates' campaigns were based on the kecamatan (subdistrict). The criteria of the respondents can be seen in Table 2. The interviews were conducted in places convenient to the respondents with short introduction about the research before giving them the questionnaire form. After completing, the respondents handed the questionnaire form back to the researcher. The researcher also read out the questions to the respondents who did not have adequate literacy skill and enough time to read the questionnaire form. The questionnaires were presented in basic Indonesian. Furthermore, the survey data were transferred to and processed by the SPSS computer software program in the numeric and string forms. For analysing the survey data, this research mainly utilized frequencies and compared means in descriptive statistics.

Second, there were semi-structured interviews with persons who had detailed, inside knowledge of the candidates, parties and elections who could be expected to utilize analytical insight in responding to questions about the reasons why people voted for particular candidates. These knowledgeable respondents were drawn from four distinctive groups on the grounds that members of each group would view the election from different perspectives and therefore provide a wide range of insights. Group 1 consisted of the leaders of political

Table 2 - Demographic characteristics of respondents

\begin{tabular}{|c|c|c|c|}
\hline No. & Demographic characteristics & Measures/Criteria & Percentage of Respondents \\
\hline \multirow[t]{5}{*}{1.} & Age & 17-27 years & 31.0 \\
\hline & & $28-38$ years & 32.0 \\
\hline & & $39-49$ years & 21.0 \\
\hline & & $50-60$ years & 15.0 \\
\hline & & More than 60 years & 1.0 \\
\hline \multirow[t]{3}{*}{2.} & Educational qualifications & Junior High School & 5.0 \\
\hline & & Senior High School & 46.0 \\
\hline & & Academy/University & 49.0 \\
\hline \multirow[t]{11}{*}{3.} & Occupation & Public servant & 13.0 \\
\hline & & State-owned enterprise worker & 15.0 \\
\hline & & Employee in private sector & 28.0 \\
\hline & & Entrepreneur & 4.0 \\
\hline & & Teacher/Lecturer & 4.0 \\
\hline & & Farmer/Fisherman/Labourer & 6.0 \\
\hline & & Student & 12.0 \\
\hline & & Housewife & 8.0 \\
\hline & & No work & 1.0 \\
\hline & & Other & 7.0 \\
\hline & & No answer & 2.0 \\
\hline \multirow[t]{2}{*}{4.} & Gender & Female & 45.0 \\
\hline & & Male & 55.0 \\
\hline
\end{tabular}

Source: Prepared by the author. 
parties at local level and heads of campaign teams, Group 2 of candidates, Group 3 of members of the local commission for general elections in Manado City (Komisi Pemilihan Umum Daerah Manado - KPUD Manado), and Group 4 of representatives of NGOs and survey organizations who monitored the election, and journalists from local media, as shown in Table 3. All groups were asked their views on voting behaviour, but Group 1 members also provided details of party organization for the 2010 local executive election.

The semi-structured interviews in this research were guided by "a clear list of issues to be addressed and questions to be answered" (Denscombe, 2010, p. 175). The list of open-ended questions used in these semi-structured interviews did not aim to limit the interviewees but encouraged them to construct ideas and talk a lot about the topic which was being discussed (Denscombe, 2010, p. 175; Robson, 2007). Before conducting interviews, the interviewees were contacted to ensure their readiness and willingness to be interviewed. The interview began with a general description of the research and tapped with the interviewee's consent. All interviewees did not mind being tapped. This helped to review the recorded discussion in order to get information and further understanding on the topic as the interviewees see it. The data obtained from the interviews was important for finding out how political parties nominated candidates, their strategies to mobilize voters and build coalitions with other local political parties, level of local autonomy and the interviewees' opinion on the factors which led the voters vote in the 2010 Manado local executive election. By adopting a thematic approach, the data was organised and classified with the help of a variety of manual and electronic research tools. Data reduction was undertaken simultaneously with the coding and categorizing process which was assisted by the computer software. After translating from Indonesian language into English language, the data were sorted into themes to help the researcher analyse the database and draw a conclusion. The results of semi-structured interview and survey data analysis were compared and contrasted with each other in order to get a better understanding on the paradoxical situation in which political parties did not and did matter.

\section{Why parties did not matter in the 2010 Manado executive election}

The survey of voters and the interviews with persons involved in the 2010 local executive election supported the view that parties were of low importance in determining the way people voted. It must, however, be acknowledged that 38 per cent of survey respondents reported agreement (32 per cent) or strong agreement $(6 \%)$ with the statement that they supported the political parties that nominated the candidates they voted for. Only 18 per cent disagreed but 44 per cent opted for a neutral response giving first indication that for voters there was more of a focus on candidates than parties.

The idea that party loyalty may be limited can also be seen through analysis of the voting figures between the legislative election of 2009 and then shortly after in 2010 the original local executive election and its re-run. There is a mixed pattern between the legislative election and the first local executive election with some parties and combinations of parties experiencing vote swings from slight losses to huge gains (see Table 1). Thus, the eight party alliance supporting Burhanuddin and Jacobus Mawuntu saw its share of the vote slip from 17.89 per cent in the legislative election to 2.65 per cent in the first local executive election while the Partai Demokrat (Democrat Party) saw its numbers rise from 14.11 per cent to 35.73 per cent over the two elections. When the re-run is brought into the picture then the volatility of voting is further evident. For example, the eight party alliance slipped from 8.20 per cent of the vote to 0.76 per cent while the three party alliance moved up from 23.16 per cent to 37.12 per 
Table 3 - Profile of the political party leaders and the heads of campaign teams ${ }^{\mathrm{I}}$, the candidates ${ }^{\mathrm{II}}$, the electoral organization members ${ }^{\mathrm{III}}$, and the observers ${ }^{\mathrm{IV}}$

\begin{tabular}{|c|c|c|c|c|c|c|c|c|c|c|}
\hline \multirow[t]{2}{*}{ No } & \multirow[t]{2}{*}{ Backgrounds } & \multirow[t]{2}{*}{ Measure/Criteria } & \multicolumn{2}{|c|}{ Group $1^{\mathrm{I}}$} & \multicolumn{2}{|c|}{ Group $2^{\text {II }}$} & \multicolumn{2}{|c|}{ Group $3^{\text {III }}$} & \multicolumn{2}{|c|}{ Group $4^{\text {IV }}$} \\
\hline & & & $\mathbf{N}^{\circ}$ & $\%$ & $\mathbf{N}^{\circ}$ & $\%$ & $\mathbf{N}^{\circ}$ & $\%$ & $\mathbf{N}^{\circ}$ & $\%$ \\
\hline \multirow[t]{6}{*}{1.} & \multirow{6}{*}{$\begin{array}{l}\text { Position in } \\
\text { Political Party }\end{array}$} & Head & 11 & 73.33 & - & - & - & - & - & - \\
\hline & & Vice Head & - & - & 1 & 14.29 & - & - & - & - \\
\hline & & Secretary & 2 & 13.33 & - & - & - & - & - & - \\
\hline & & Member of Executive Board & - & - & 2 & 28.57 & - & - & - & - \\
\hline & & Head of Campaign Team & 2 & 13.33 & - & - & - & - & - & - \\
\hline & & No position & - & - & 4 & 57.14 & - & - & - & - \\
\hline \multirow[t]{4}{*}{2.} & \multirow{4}{*}{$\begin{array}{l}\text { Year to Join } \\
\text { Political Party }\end{array}$} & 1986-1995 & 4 & 26.67 & 1 & 14.29 & - & - & - & - \\
\hline & & $1996-2005$ & 2 & 13.33 & - & - & - & - & - & \\
\hline & & $2005-2012$ & 6 & 40.00 & 2 & 28.57 & - & - & - & - \\
\hline & & No answer & 3 & 20.00 & 4 & 57.14 & - & - & - & - \\
\hline \multirow[t]{13}{*}{3.} & \multirow[t]{13}{*}{ Occupation } & Head of DPRD Manado & 1 & 6.67 & - & - & - & - & - & - \\
\hline & & Member of DPRD Manado & 12 & 80.00 & - & - & - & - & - & - \\
\hline & & Entrepreneur & 1 & 6.67 & 3 & 42.86 & - & - & - & - \\
\hline & & $\begin{array}{l}\text { Reverend of one of Christian } \\
\text { Denomination Churches }\end{array}$ & 1 & 6.67 & - & - & - & - & - & - \\
\hline & & Lawyer & - & - & 1 & 14.29 & - & - & - & - \\
\hline & & $\begin{array}{l}\text { Former Mayor of Manado } \\
\text { City }\end{array}$ & - & - & 1 & 14.29 & - & - & - & - \\
\hline & & Member of DPD/MPR RI & - & - & 1 & 14.29 & - & - & - & - \\
\hline & & Public Servant & - & - & 1 & 14.29 & - & - & - & - \\
\hline & & Member of KPU Manado & - & - & - & - & 4 & 100 & - & - \\
\hline & & Journalist & - & - & - & - & - & - & 8 & 72.73 \\
\hline & & Member of KIP Sulut & - & - & - & - & - & - & 1 & 9.09 \\
\hline & & NGO & - & - & - & - & - & - & 1 & 9.09 \\
\hline & & Survey Organization & - & - & - & - & - & - & 1 & 9.09 \\
\hline \multirow[t]{5}{*}{4.} & \multirow{5}{*}{$\begin{array}{l}\text { Educational } \\
\text { Background }\end{array}$} & Senior High School & 1 & 6.67 & 1 & 14.29 & - & - & 2 & 18.18 \\
\hline & & Diploma & 2 & 13.33 & - & - & - & - & - & - \\
\hline & & Bachelor & 9 & 60.00 & 4 & 57.14 & 1 & 25 & 8 & 72.73 \\
\hline & & Master & 3 & 20.00 & 1 & 14.29 & 3 & 75 & 1 & 9.09 \\
\hline & & Doctor & - & - & 1 & 14.29 & - & - & - & - \\
\hline \multirow[t]{2}{*}{5.} & \multirow[t]{2}{*}{ Gender } & Male & 12 & 80.00 & 7 & 100 & 3 & 75 & 10 & 90.91 \\
\hline & & Female & 3 & 20.00 & - & - & 1 & 25 & 1 & 9.09 \\
\hline \multirow[t]{6}{*}{6.} & \multirow[t]{6}{*}{ Ages } & $17-29$ & - & - & - & - & - & - & 2 & 18.18 \\
\hline & & $30-39$ & 3 & 20.00 & 1 & 14.29 & 1 & 25 & 7 & 63.64 \\
\hline & & $40-49$ & 9 & 60.00 & 3 & 42.86 & 2 & 50 & 2 & 18.18 \\
\hline & & $50-59$ & 2 & 13.33 & 1 & 14.29 & 1 & 25 & - & - \\
\hline & & 60 above & - & - & 2 & 28.57 & - & - & - & - \\
\hline & & No answer & 1 & 6.67 & - & - & - & - & - & - \\
\hline
\end{tabular}

Source: prepared by the author.

IPolitical Party Leaders and Heads of Campaign Teams.

${ }^{\text {II } C a n d i d a t e s . ~}$

IIIElectoral Organizations.

${ }^{\mathrm{IV}}$ Observers. 
cent. Overall, the numbers do suggest the existence of some party loyalty among voters but the sometimes considerable variation in the numbers of votes for particular political parties between elections also tells us that many people are influenced by factors other than allegiance to parties and that changes in voting behaviour can happen rapidly over the short-term.

This suggestion of the limited relevance of parties was borne out in subsequent responses from voters and experts. Thus, 72.4 per cent of survey respondents agreed or strongly agreed that their voting decisions were influenced by the candidates' personalities (see Table 4). Having a favourable view of a candidate's experience and ability to lead also brought a high proportion of agree (47 per cent) and strongly agree ( 26 per cent) responses. The perceived closeness of the preferred candidate to the community was strongly supported, with 46 per cent agreeing and 28 per cent strongly agreeing. Over half respondents agreed that candidates' speeches influenced their votes while voters reported that media exposure of candidates had major impact on their choices in the election. There was also recognition of the importance of candidate's visions for the future of Manado City with 71.1 per cent agreeing that candidates' programmes for Manado City's development influenced their voting. Items that may have affectively tied voters to candidates were perceived as less important than the personality, ability and vision of the candidates. For example, only 23 per cent agreed that gifts from a candidate influenced their vote, 11.1 per cent said that being a friend of a candidate influenced their behaviour while a mere 14 per cent identified ethnicity as being significant. But 40.8 per cent agreed that having a friend in a candidate's campaign team did influence their vote. Approximately

Table 4 - Voters' views on factors affecting the local government election (in valid per cent)

\begin{tabular}{lccc}
\hline Factors & Agree & Neutral & Disagree \\
\hline Supporting the party which nominates the candidate & 38 & 44 & 18 \\
Programmes of candidates & 71.1 & 23.7 & 5.1 \\
Family relationship & 3 & 16 & 81 \\
Friend of the candidate & 11.1 & 15.2 & 73.8 \\
Religion & 51 & 16 & 33 \\
Ethnicity or residential area & 14 & 16 & 70 \\
Having a friend in the candidate's campaign team & 40.8 & 12.2 & 46.9 \\
Gifts from the candidate & 16 & 7 & 77 \\
Promises by the candidate & 22.4 & 10.2 & 67.3 \\
Being visited by the candidate & 7 & 10 & 83 \\
Meeting the candidate in public places & 32 & 16 & 52 \\
The candidate's speeches & 54.5 & 33.3 & 12.1 \\
Personality of candidate & 72.4 & 20.4 & 7.1 \\
The candidate's experience and ability to lead & 73 & 24 & 3 \\
Campaign paraphernalia & 39 & 26 & 35 \\
Asked by the candidate's campaign team & 21.2 & 17.2 & 61.7 \\
Television & 61.6 & 18.2 & 20.2 \\
Newspapers & 79 & 16 & 5 \\
Radio & 56 & 19 & 25 \\
Persuasive campaigns of candidates & 40 & 51 & 9 \\
Close to the community & 74 & 22 & 4 \\
\hline
\end{tabular}

Source: prepared by the author. 
half the respondents also identified having the same religion was a factor that influenced their voting decisions.

Interviews with people in organizations engaged in electoral activities added further weight to the perceived unimportance of political parties in the 2010 executive election (see Table 5). One question sought opinions on whether candidates' loyalty and commitment to political parties was a quality needed to win in the election. All the candidates (Group 2) and members of the local commission for elections in Manado City (Group 3) thought that parties were unimportant. Almost three-quarters (72.73 per cent) of the representatives of NGOs,

Table 5 - Respondents' views on factors affecting the local government election

\begin{tabular}{|c|c|c|c|c|c|}
\hline $\begin{array}{l}\text { Factors affecting the local } \\
\text { government election }\end{array}$ & Answers & Group I & Group II & Group III & Group IV \\
\hline \multirow[t]{4}{*}{ Policy programmes } & Important & 60 & 28.57 & 75 & 45.45 \\
\hline & Unimportant & 33.33 & 42.86 & 25 & 54.55 \\
\hline & Neither & 0 & 28.57 & 0 & 0 \\
\hline & No response & 6.67 & 0 & 0 & 0 \\
\hline \multirow[t]{4}{*}{ Party allegiances } & Important & 46.67 & 0 & 0 & 0 \\
\hline & Unimportant & 53.33 & 100 & 100 & 72.73 \\
\hline & Neither & 0 & 0 & 0 & 18.18 \\
\hline & No response & 0 & 0 & 0 & 9.09 \\
\hline \multirow[t]{4}{*}{ Lack of commitment } & Important & 73.33 & 100 & 100 & 81.82 \\
\hline & Unimportant & 26.67 & 0 & 0 & 9.09 \\
\hline & Neither & 0 & 0 & 0 & 0 \\
\hline & No response & 0 & 0 & 0 & 9.09 \\
\hline \multirow[t]{4}{*}{ Personality } & Important & 86.67 & 85.71 & 100 & 72.73 \\
\hline & Unimportant & 13.33 & 14.29 & 0 & 9.09 \\
\hline & Neither & 0 & 0 & 0 & 9.09 \\
\hline & No response & 0 & 0 & 0 & 9.09 \\
\hline \multirow[t]{4}{*}{ Family } & Important & 46.67 & 85.71 & 100 & 63.64 \\
\hline & Unimportant & 6.67 & 14.29 & 0 & 27.27 \\
\hline & Neither & 46.67 & 0 & 0 & 0 \\
\hline & No response & 0 & 0 & 0 & 9.09 \\
\hline \multirow[t]{4}{*}{ Ideology } & Important & 33.33 & 57.14 & 50 & 0 \\
\hline & Unimportant & 33.33 & 42.86 & 25 & 90.91 \\
\hline & Neither & 33.33 & 0 & 25 & 0 \\
\hline & No response & 0 & 0 & 0 & 9.09 \\
\hline \multirow[t]{4}{*}{ Religion } & Important & 46.67 & 42.86 & 50 & 45.46 \\
\hline & Unimportant & 26.67 & 57.14 & 50 & 45.46 \\
\hline & Neither & 0 & 0 & 0 & 0 \\
\hline & No response & 26.67 & 0 & 0 & 9.09 \\
\hline \multirow[t]{4}{*}{ Sources of voting advice } & Important & 13.33 & 57.14 & 50 & 63.64 \\
\hline & Unimportant & 20 & 0 & 0 & 0 \\
\hline & Neither & 20 & 14.29 & 50 & 9.09 \\
\hline & No response & 46.67 & 28.57 & 0 & 27.27 \\
\hline
\end{tabular}

Source: prepared by the author. 
survey organizations and journalist that monitored the election (Group 4) judged parties to be unimportant. None in this group thought the factor was important. Only the party leaders and heads of the campaign teams (Group 1) awarded significance to party allegiances with slightly almost half (46.67 per cent) viewing the factor as important. This view of party importance of Group 1 was not surprising given that they were leading party officials who might think it inappropriate to give low importance to the organizations they represented. Despite this support, a slight majority of Group 1 (53.33 per cent) still thought party allegiance was unimportant. These responses were supplemented by asking whether respondents saw a trend of voter lack of commitment to political parties in the 2010 executive election. There was overwhelming agreement that there was a growing lack of commitment. Thus, all of Group 2 and 3 participants believed that commitment of voters to parties was of little or no significance. Even 73.33 per cent of the party personnel shared this view as did 81.82 per cent of Group 4.

The most important factor for electoral success according to all the groups was the candidates' personalities. This was affirmed by 85.71 per cent of Group 2, all of Group 3, 72.73 per cent of Group 4, and even 86.67 per cent of the officials of parties and their candidates. There was variation between groups and among groups on other factors. For example, policy programmes were awarded importance by Group 3 (75 per cent) and Group 1 (60 per cent) but received much lower scores from the other two groups. Ideology was only seen as important by 33.33 per cent of Group 1, 57.14 per cent of Group 2, 50 per cent of Group 3 and 0 per cent from Group 4. Family was viewed as more significant with 46.67 per cent of Group 1, 85.71 per cent of Group 2, 100 per cent of Group 3 and 72.73 per cent of Group 4 considering that a candidate's family standing was important. This aspect of the candidates can of course be viewed as part of their overall personal qualities.

Comparing the results of the voter survey and the interviews with persons involved in contesting, organizing and commenting on the election reveals broad agreement with the proposition that parties didn't matter. The commentators (Groups 1-4) universally viewed parties as having little effect on voting behaviour. This included those who belonged to parties or were their candidates. The voters surveyed were more inclined to follow their party preferences although this was still a minority position. For all research participants, the major influence on how people voted was perceived to be the personalities of the candidates. Other factors came into the picture. However, no clear pattern emerged as to what was considered a winning cluster of personal attributes with different respondents allocating importance or unimportance to a range of variables.

\section{Why parties did matter in the 2010 Manado City executive election}

Although interviewees and the voter survey concur on the unimportance of political parties in determining voting behaviour, there is other evidence that indicates they may have played a significant role. The evidence concerns the roles of parties in political mobilization, a process of encouraging people to participate in political actions (Rosenstone \& Hansen, 1993). One result of political mobilization is voting. Political parties are often key actors in getting people mobilized to vote and in influencing their voting decisions. In the 2010 local government election in Manado, the political parties were influential in such political mobilization. The candidates sought political party endorsement to contest the 2010 election. Those who could not secure political party backing could run independently. This happened to three of the candidates as shown in Table 1. Two of these independents received the lowest numbers of votes among all the candidates - 204 votes or 0.11 per cent of the total and 934 votes or 0.49 per 
cent of the total. The other independent candidate received 1,329 votes, slightly ahead of the worst performing party-backed candidate.

The common perception among the candidates was that without party backing they had little chance of winning. But it was not the party name that was the attraction for the candidate. It was the organizational support that appears to have been the critical drawcard. The parties were perceived as knowing how to conduct election campaigns, how to project the images of the candidates, how to gather supporters together and allocate them tasks for the candidates' campaigns. The strategy of the parties was to recruit candidates who were popular in the community. They gauged this popularity by conducting surveys well before the election to see which personalities and potential candidates were attractive to the public. Seven out of thirteen party officials and candidates interviewed for this research named surveys as the principal way of identifying and then recruiting candidates. However, smaller parties lacked the funds to pay for such surveys and had to rely on independent surveys, media reports and party board perceptions. Six out of thirteen interviewees also stated that they opened up the nomination process to the public and then the party's city board would assess the chances of the nominees to win the election rather than their ideological commitment or record of loyalty to the party. There was a reciprocal courtship between parties and candidates to determine who would stand under which party's banner and who would fail to secure nomination. Ideology and previous association with the parties were of little concern in determining who stood for which party or group of parties. The key concern of both candidate and party was winning.

For the popular potential candidates, it did not require much effort to attract the attention of Manado's political parties. But for the less popular potential candidates, it required a lot of money to boost their popularity and hence attractiveness to the parties. Some party candidates even admitted that they made surreptitious payments to the political parties both at the local and national level to secure nomination. But all parties expected their candidates to provide much of the finance for the campaigns. In fact, political parties had limited budgets for their candidates' campaigns and expected the candidates to shoulder much of the financing requirements. Thus, parties sought candidates who were not only popular but also had plentiful financial resources. This money paid for the local party apparatus that was created to fight the election and the expenses incurred in campaigning. A final requirement of candidates was that they had personal networks which could be utilized for acquiring votes as popularity alone might be insufficient.

The parties in Manado City adopted very similar organizational structures for the 2010 local government election. Each party operated at three levels - the city, the subdistrict (kecamatan) and the urban village (kelurahan) - with party boards at each level being key decision-making and resource-marshalling bodies. Meetings in the kecamatan and kelurahan facilitated the introduction of the pairs of candidates to a broad spectrum of grass roots party officials and workers and familiarized them with election strategies. The party organizations grew in size for the elections as campaign workers were recruited by the parties to undertake the enormous increase in party workload for electoral mobilization. In general, the parties had specific job descriptions for members of the election teams varying according to the tasks allocated to different levels in the parties' territorial hierarchies. The jobs were mainly given to party members based on their skills and most campaign workers undertook these roles on a voluntary basis.

Most parties made efforts to recruit new members during the campaign period. Qualifications for membership were minimal with parties looking for nu- 
merical strength rather than ideological identification with the party. A range of similar activities was conducted by the parties to mobilize voters to align with their candidates. The activities included charity work, "socializing" the party programmes, social activities and "consolidating" the party to give it internal strength and coherence.

The significance of party support in the 2010 local government elections in Manado City can be seen in the election results. The three independent candidates received only 2,230 votes, 1.3 per cent of the total, while the candidates backed by political parties obtained 187,309 votes, 98.7 per cent of the total. Thus, political parties were crucial for election success. While people voted for individuals according to personality and other factors, they did not do so if the individual candidate did not belong to a party. It was parties that mobilized voters using their organizational skills and personnel to support candidates who were then judged by the electorate according to their personal characteristics. This leads to the hypothesis that voters in the 2010 local government election in Manado City were more comfortable with the candidates who were backed by political parties. And the parties were more comfortable with the candidates who were already popular and had financial resources.

A final factor relating to parties is the degree of autonomy of the local branches in determining who would be the pair of candidates. Six out of thirteen party officials and candidates stated that the local party offices were given the responsibility for selecting the candidates. Four others spoke of the delegation of authority by central party offices to the local level. However, candidates selected by the local party branch still needed approval by the central party office. This right of veto was exercised by some central party offices in the 2010 local government election in Manado City. For the thirteen parties in Manado City for which I have data on candidate choices, six had their locally proposed candidate vetoed by the parties' central offices and replaced with a candidate preferred by the central office (see Table 6). The central party office held similar rights over party coalition building. Thus, when the central party offices vetoed a candidate nominated by the local party office this could trigger a realignment

Table 6 - The candidates proposed by the local offices and approved by the central offices of political parties

\begin{tabular}{lcc}
\hline Political Parties & $\begin{array}{c}\text { Candidates proposed by the local offices of } \\
\text { the political parties }\end{array}$ & $\begin{array}{c}\text { Candidates approved by the central offices of } \\
\text { the political parties }\end{array}$ \\
\hline GOLKAR & Vicky Lumentut & Hanny Joost Pajouw \\
PD & Vicky Lumentut & Vicky Lumentut \\
PDIP & Jackson Kumaat & Marhany Victor Pua \\
GERINDRA & Meiby Saerang (proposed for first time), Mei & Yongkie Limen \\
Handoko (proposed for second time) & \\
HANURA & Hanny Joost Pajouw & Jackson Kumaat \\
PAN & Hanny Joost Pajouw & Hanny Joost Pajouw \\
PDS & Vicky Lumentut & Marhany Victor Pua \\
PPP & Burhanuddin & Burhanuddin \\
PKS & Jackson Kumaat & Jackson Kumaat \\
PKPB & Yongkie Limen & Yongkie Limen \\
BARNAS & Vicky Lumentut & Hanny Joost Pajouw \\
PDK & Jackson Kumaat & Jackson Kumaat \\
Partai Buruh & Jackson Kumaat & Jackson Kumaat
\end{tabular}

Source: prepared by the author. 
of parties at the local level. The lack of strong ideological positions by all parties at the local level meant that realignment of party coalitions could be fairly easily accomplished. Central party offices did not interfere in the election campaigns as they realized the greater understanding by the local offices of the conditions in Manado City and hence the best strategies and tactics to adopt.

\section{Discussion}

The description and analysis of the 2010 local executive election in Manado City has demonstrated the complexity and volatility of local politics and also that a paradox may be evident; that is, situations can occur in which parties both do and don't matter in local elections. This empirical possibility has been revealed for Manado City by utilising a multi-perspective methodology in which different groups of stakeholders provided their particular views on aspects of electoral politics, specifically the 2010 election for the local chief executive. Thus, the opinions of voters, party officials, candidates, election officials, NGO and survey personnel, and media workers were sought in order to build a comprehensive picture of election events and their interpretation. This case study methodology allowed triangulation of multiple stakeholders' responses and while there were differences of opinion on some matters between stakeholders and inside particular stakeholder groups, two clear patterns emerged: that political parties did and didn't matter.

Support for the "parties don't matter" perspective derived from two major sources. First was the variation in voting figures over three elections held close together in Manado City. The legislative election was followed by the local executive election and then the re-run of that election, all in the space of just over a year. The significant changes in the votes obtained by political parties suggested that many in the electorate were not demonstrating party allegiance despite a substantial minority saying that they did vote along party lines.

This led to the second major finding that indicated many people paid little attention to parties when casting their votes for the local chief executive. This was the revelation that the "personality" of candidates and the programmes they were espousing were the key elements in determining how people would vote. There was, however, no agreed combination of character traits, individual behaviours and achievements that influenced people's votes. Different combinations were held to be important by the various stakeholders but there was widespread agreement that voters primarily looked to the personal characteristics of the candidates when making up their minds as to who to cast their ballot for. They also sought attractive programmes of development that were seen to be both desirable and achievable.

Beside the candidates' political parties, the voters also have little attention on the candidates' party membership. Some candidates had long been members of their political parties but others recently moved from their party to the party that nominated them. Table 6 shows that most candidates moved to other political party when they did not get approval from their party's central office to compete in the election. This indicates that the political parties did not matter because the candidates were easy to transfer from their political party to other parties in order to get the party recommendation to fight in the election. Moreover, the voters did not care about their candidates' party membership in the party.

Support for the "parties do matter" perspective came from the perceived organizational effectiveness of party election machinery. Candidates sought parties because they wished to avail themselves of the networks parties had throughout Manado City starting at the city level but extending downwards into 
the lower level territories of kecamatan and kelurahan. For candidates, this meant that an apparatus was in place throughout all areas of Manado City down to the grassroots and this apparatus had personnel, structure and organizational abilities to canvas the candidate to the population everywhere. Independent candidates had to construct their canvasing structures and processes from scratch and lacked the experience and organizational reach of the parties.

But it was a reciprocal arrangement as parties needed candidates and were interested in candidates who seemed to have a good chance of winning. Ideological commitment to parties was of minor concern compared to the perceived popularity of potential candidates. The lack of clear ideological distinctions between parties at the local level helped to facilitate this process. As long as candidates claimed allegiance to the party or parties they lined up for, then both parties and candidates were satisfied. Some candidates in the 2010 election had switched parties from earlier times thus indicating the instability of the alignments between parties and candidates for the next elections.

\section{Conclusion}

This study of the local executive election in Manado City in 2010 has advanced the study of such elections beyond the excellent foundational work of the researchers in the pioneering collection of Erb and Sulistiyanto (2009) on the 2005 and 2006 local executive elections. Various authors in that volume had identified the declining importance of national political parties in electoral competition at the local level and the move towards people voting for individuals based on some sort of assessment of their personal attractiveness or other characteristics. This research on Manado City does not dispute any of the earlier findings but drills down further to examine what parties actually do in the elections, what motivates them to engage strongly in the contest, and how the voters react to them. This led to the extension of our knowledge beyond the Erb and Sulistiyanto (2009) volume where the researchers did not scrutinize what parties were doing in any great detail. This Manado City study set out to understand the role parties play in local executive elections and the significance of that role for electoral success. It exposed the paradox that parties do and do not matter. They do not matter because people largely vote for individuals and not for parties but they do matter because of the organizational networks and skills they bring to electoral competition. This article does not claim that the situation that prevailed in 2010 in Manado City applies elsewhere in Indonesia. Indeed, as the Erb and Sulistiyanto (2009) volume clearly demonstrates, the dynamics of local political competition can vary considerably across the Indonesian archipelago according to the contrasting contexts in which elections are conducted. However, it is useful for future research to consider more closely the role of parties in local elections.

Stefanus Sampe (stefanus_sampe@ unsrat.ac.id) is a doctor of philosophy by the University of Canberra, and is currently professor at Universitas Sam Ratulangi.

\section{References}

Bardhan, P. \& Mookherjee, D. (2006) Decentralization and Local Governance in Developing Countries: A Comparative Perspective. Cambridge, Mass.: MIT Press.

Buehler, M. (2009) The Rising Importance of Personal Networks in Indonesian Local Politics: An Analysis of District Government Head Elections in South Sulawesi in 2005. In: M. Erb \& P. Sulistiyanto (eds). Deepening Democracy in Indonesia: Direct Elections for Local Leaders (Pilkada). Singapore: Institute of Southeast Asian Studies, pp. 101-124.

Cheema, S.G. \& Rondinelli, D. (eds) (2007) Decentralizing Governance: Emerging Concepts and Practices. Washington DC: Harvard University and Brookings Institution. 
Choi, N. (2009) Batam's 2006 Mayoral Election: Weakened Political Parties and Intensified Power Struggle in Local Indonesia. In: M. Erb \& P. Sulistiyanto (eds). Deepening Democracy in Indonesia: Direct Elections for Local Leaders (Pilkada). Singapore: Institute of Southeast Asian Studies, pp. 74-100.

Denscombe, M. (2010) The Good Research Guide: For Small-scale Social Research Projects, $4^{\text {th }}$ ed. New York: Open University Press.

Devas, N. (1997) Indonesia: What do We Mean by Decentralisation? Public Administration and Development, 17(3), pp.351-368.

Erb, M. \& Sulistiyanto, P. (eds) (2009) Deepening Democracy in Indonesia: Direct Elections for Local Leaders (Pilkada). Singapore: Institute of Southeast Asian Studies.

Erb, M. \& Anggal, W. (2009) Conflict and the Growth of Democracy in Manggarai District. In: M. Erb \& P. Sulistiyanto (eds). Deepening Democracy in Indonesia: Direct Elections for Local Leaders (Pilkada). Singapore: Institute of Southeast Asian Studies, pp. 283-302.

Hidayat, S. (2009) Pilkada, Money Politics and the Dangers of 'Informal Governance’ Practices. In: M. Erb \& P. Sulistiyanto (eds). Deepening Democracy in Indonesia: Direct Elections for Local Leaders (Pilkada). Singapore: Institute of Southeast Asian Studies, pp. 125-146.

Ho, B. (2014) Village Democracy Shrugs in Rural China. 22 July 2014. East Asia Forum [online]. Available through: <http://www.eastasiaforum.org/2014/07/22/village-democracy-shrugs-in-rural-china/>. Accessed at 27 aug. 2021.

Holtzappel, C. \& Ramstedt, M. (2009) Decentralisation and Regional Autonomy in Indonesia: Implementation and Challenges. Singapore: Institute of Southeast Asian Studies.

Lewis, B., (2005) Indonesian Local Government Spending, Taxing and Saving: An Explanation of Pre- and Post-decentralisation Outcomes. Asian Economic Journal, 19(3), pp.291-317. DOI: 10.1111/j.1467-8381.2005.00214.x

Lindsay, J. (2009) Pomp, Piety and Performance: Pilkada in Yogyakarta, 2005. In: M. Erb \& P. Sulistiyanto (eds). Deepening Democracy in Indonesia: Direct Elections for Local Leaders (Pilkada), Singapore: Institute of Southeast Asian Studies, pp. 211-228.

Litvack, J., Ahmad, J. \& Bird, R. (1998) Rethinking Decentralization in Developing Countries. Washington DC: World Bank.

Mattner, M. (2004) Power to the People? Local Governance and Politics in Vietnam. Environment and Urbanization, 16(1), pp.121-128. DOI: 10.1177/095624780401600110

Mboi, A. (2009) Pilkada Langsung: The First Step on a Long Road to a Dualistic Provincial and District Government. In: M. Erb \& P. Sulistiyanto (eds). Deepening Democracy in Indonesia: Direct Elections for Local Leaders (Pilkada). Singapore: Institute of Southeast Asian Studies, pp. 38-49.

Pratikno (2009) Political Parties in Pilkada: Some Problems for Democratic Consolidation. In M. Erb \& P. Sulistiyanto (eds). Deepening Democracy in Indonesia: Direct Elections for Local Leaders (Pilkada). Singapore: Institute of Southeast Asian Studies, pp. 53-73.

Robson, C. (2007) How to Do a Research Project: A Guide for Undergraduate Students. Somerset: Blackwell Publishing.

Rohdewohld, R. (1995) Public Administration in Indonesia. Melbourne: Montech.

Rosenstone, S. \& Hansen, J. (1993) Mobilization, Participation and Democracy in America. New York: Macmillan.

Satriyo, H. (2010) Pushing the Boundaries: Women in Direct Local Elections and Local Government. In: E. Aspinall \& M. Mietzner (eds). Problems of Democratization in Indonesia: Elections, Institutions and Society. Singapore: Institute of Southeast Asian Studies, pp. 243-263.

Subianto, B. (2009) Ethnic Politics and the Rise of the Dayak-bureaucrats in Local Elections: Pilkada in Six kabupaten in West Kalimantan. In: M. Erb \& P. Sulistiyanto (eds). Deepening Democracy in Indonesia: Direct Elections for Local Leaders (Pilkada). Singapore: Institute of Southeast Asian Studies, pp. 327-351.

Sulistiyanto, P. (2009) Pilkada in Bantul District: Incumbent, Populism and the Decline of Royal Power. In: M. Erb \& P. Sulistiyanto, eds. Deepening Democracy in Indonesia: Direct Elections for Local Leaders (Pilkada). Singapore: Institute of Southeast Asian Studies, pp. 190-208.

Tsebelis, G. (2002) Veto Players: How Political Institutions Work. Princeton, NJ: Princeton University Press.

Turner, M. (2006) From Commitment to Consequences: Comparative Experiences of Decentralization in the Philippines, Indonesia and Cambodia. Public Management Review, 8(2), pp.253-272.

Turner, M. \& Podger, O. (2003) Decentralisation in Indonesia: Redesigning the State. Canberra: Asia Pacific Press.

\section{Others sources}

BPS Sulut (Badan Pusat Statistik Sulawesi Utara/Statistics Indonesia) (2010) Sulawesi Utara Dalam Angka 2010 (North Sulawesi in figures 2010). Manado: BPS Propinsi Sulawesi Utara.

Mahkamah Konstitusi Republik Indonesia (Constitutional Court of the Republic of Indonesia) (2010) Decision of the Constitutional Court of the Republic of Indonesia No. 144/PHPU.D-VIII/2010 on disputes over the results of 2010 regional head and deputy regional head election in Manado. Available through:

$<$ https://mkri.id/public/content/persidangan/putusan/putusan_sidang_PUTUSAN\%20PSU\%20144\%20MANADO\%20telah_baca.pdf>. Accessed at 27 aug. 2021.

Mujani, S. \& Liddle, W. (2009) Voter Preferences for Presidential/Vice-presidential Candidates: Public Opinion Trends. Lembaga Survei Indonesia. Jakarta, 25-30 May.

World Bank (2005) East Asia Decentralizes. Washington DC: World Bank. 


\section{Newspaper articles}

FOX: Manado Dua Putaran. (2010) Manado Post, Manado, Tuesday 13 Jul. Available at: $<$ https://issuu.com/manadopost/docs/mp130710>. Accessed at 27 aug. 2021.

Tribun Manado (2010a) KPU Manado Putuskan Pilwako 29 September. Tribun Manado, 4 May. Available through: $<$ http://m.tribunnews.com/election/2010/05/04/kpu-manado-putuskan-pilwako-29-september>. Accessed at 27 aug. 2021.

Tribun Manado (2010b) “Amboy! Satu Pemilih Dijanjikan Rp. 1.250.000.” Tribun Manado, 3 August. Available through: $<\mathrm{http}: / /$ m.tribunnews.com/election/2010/08/03/amboy-satu-pemilih-dijanjikan-rp-1.250.000>. Accessed at 27 aug. 2021.

\section{Glossary}

BARNAS - Barisan Nasional (National Front)

BPS - Badan Pusat Statistik (Statistics Indonesia)

Bupati - Head of District/Region

Camat - Head of Subdistrict

DPD - Dewan Perwakilan Daerah (Region's Representative Council)

DPRD - Dewan Perwakilan Rakyat Daerah (Regional People's Representative Council)

GERINDRA - Gerakan Indonesia Raya (Great Indonesian Movement)

GOLKAR - Golongan Karya (Functional Groups)

HANURA - Hati Nurani Rakyat (People's Conscience Party)

Kabupaten - District headed by a bupati elected by the district people in the local election

Kecamatan - Subdistrict headed by a camat appointed by bupati or walikota

Kelurahan - Urban Village headed by a lurah appointed by bupati or walikota

KIP - Komisi Informasi Publik (Public Information Commission)

Kota - City

KPU - Komisi Pemilihan Umum (General Election Commission)

KPUD - Komisi Pemilihan Umum Daerah (Regional General Election Commission)

Lurah - Head of Urban Village

MPR - Majelis Permusyawaratan Rakyat (People's Consultative Assembly)

NDI - National Democratic Institute for International Affairs

PAN - Partai Amanat Nasional (National Mandate Party)

Partai Buruh - Labour Party

PD - Partai Demokrat (Democratic Party)

PDI-P - Partai Demokrasi Indonesia Perjuangan (Indonesian Democratic Party - Struggle)

PDK - Partai Demokrasi Kebangsaan (National Democratic Party)

PDS - Partai Damai Sejahtera (Prosperous Peace Party)

Pilkada - Pemilihan Kepala Daerah (Local Executive Election)

PKPB - Partai Karya Peduli Bangsa (Nationhood and Caring Party)

PKS - Partai Keadilan Sejahtera (Prosperous Justice Party)

PPP - Partai Persatuan Pembangunan (United Development Party)

Propinsi - Province

Walikota - Mayor 
Por que os partidos políticos não importam e importam nas eleições do governo local na Indonésia: O caso da Cidade de Manado

Palavras-chave: descentralização; países em desenvolvimento; Indonésia; eleição local; partidos políticos.

RESUMO Introdução: Apesar da descentralização atribuir crescentes poderes de tomada de decisão aos governos subnacionais em toda a Ásia, o assunto das eleições locais não recebeu nem de longe a atenção acadêmica concedida às eleições nacionais. Este artigo tem como objetivo contribuir para preencher esta lacuna na literatura sobre a dinâmica das eleições locais, examinando as eleições executivas locais de 2010 na Indonésia, através do estudo de caso detalhado da Cidade de Manado. Materiais e Métodos: Este artigo usou uma combinação de metodologias quantitativas e qualitativas para um estudo de caso da eleição do governo local de Manado em 2010. Esses métodos incluem observação direta realizada durante a eleição em 2010, revisão de artigos e livros relevantes da mídia, coleta de estatísticas de organizações governamentais relevantes e entrevistas. Este último compreendeu o aspecto mais importante e inovador da pesquisa. As entrevistas foram de dois tipos, Primeiro, houve uma pesquisa quantitativa com 100 entrevistados selecionados usando questionário com 22 perguntas fechadas. Segundo, houve entrevistas semiestruturadas com os líderes locais dos partidos políticos, os chefes das equipes de campanha, os candidatos, os membros da organização eleitoral local, os representantes das ONGs, o pessoal da mídia de massa e as organizações de pesquisa que monitoraram a eleição. Os dados quantitativos foram explorados com o auxílio de um programa de aplicação em computador (SPSS), enquanto os dados qualitativos foram analisados por meio de uma abordagem temática. Embora a coleta e análise qualitativa de dados tenham sido dominantes, a metodologia quantitativa ainda era importante neste artigo. Resultados: Este artigo encontrou uma situação paradoxal em que os partidos políticos não importaram e importaram. A situação em que eles não importaram foi apoiada por evidências mostrando que os eleitores escolheram candidatos com base em suas personalidades, comportamentos e programas, em vez de na lealdade do partido. Na situação contrária, no caso em que os partidos realmente importavam, isso derivou das habilidades organizacionais superiores dos partidos na execução de campanhas eleitorais bem-sucedidas e no alinhamento com os candidatos com maior probabilidade de vitória. Discussão: Este artigo foi um acréscimo valioso para explicar as atividades dos partidos políticos em nível local no contexto da descentralização. A implicação desta pesquisa é que, embora os eleitores não tenham escolhido os partidos políticos, eles foram altamente significativos na determinação do resultado das eleições para o governo local na cidade de Manado. Portanto, é útil para pesquisas futuras considerar mais de perto o papel dos partidos políticos nas eleições locais.

This is an Open Access article distributed under the terms of the Creative Commons Attribution Non-Commercial License which permits unrestricted non-commercial use, distribution, and reproduction in any medium provided the original work is properly cited. 